Ks. Waldemar TUREK

(Roma, Pontificia Università Urbaniana)

\title{
„UCZYŃMY CZŁOWIEKA NA NASZ OBRAZ, PODOBNEGO NAM" (Rdz 1, 26) W INTERPRETACJI TERTULIANA
}

Pisarze okresu patrystycznego odwoływali się wielokrotnie w swojej refleksji tcologicznej do Księgi Rodzaju ukazującej szczególną pozycję człowieka w hierarchii stworzeń. Słynne zdanie „Uczyńmy człowieka na Nasz obraz, podobnego Nam" ( $\mathrm{Rdz} 1,26)$ stanowiło bazę rozważań dotyczących wielu tematów omawianych przez Ojców Kościoła. Co jednak w praktyce oznaczają „obraz” i „podobieństwo”? Według interpretacji biblistów „obraz” (selem) należy interpretować w wymiarze konkretnym jako figurę plastyczną, która odzwierciedla oryginał „podobieństwo” (demut) natomiast ma charakter abstrakcyjny i ukazuje analogię osób bądź rzeczy ${ }^{1}$.

Tekstem zamieszczonym w Księdze Rodzaju 1,26 zajął się Tertulian († po 220 r. $)^{2}$, komentując go i wykorzystując zwłaszcza w tych pismach, w których podejmował niezwykle wówczas aktualne $\mathrm{i}-\mathrm{w}$ pewnej mierze - delikatne kwestie teologiczne. Interesujące nas słowa Pisma Świętego znalazły właśnie w egzegezie Tertuliana wieloraką interpretację, ukazującą szczególne powołanie i zadanie czlowicka, jakimi obdarował go Bóg już $w$ akcie stworzenia. Analizując odnośne teksty pisarza, spróbujemy odpowiedzieć, jak postrzega on człowieka w świetle tekstu $\mathrm{Rdz} 1,26$, i jakie wyciąga $\mathrm{z}$ tego konsekwencje antropologiczne i teologiczne.

${ }^{1} \mathrm{M}$. Cimosa, La rivelazione della „grazia divina" nell'Antico Testamento (= Dizionario di Spiritualità Biblico-Patristica 30, Roma 2002), 22: „Immagine (selem) ha un significato concreto e indica la "figura" plastica che riproduce un modello: somiglianza (demut) è invece astratto e indica la somiglianza di una persona o di una cosa con un'altra".

2 Zainteresowanych bibliografią dotyczącą życia i działalności Tertuliana, zresztą bardzo obszerną, odsyłam do opracowań: G. Azzali Bernardelli, Tertulliano, w: G. Bosio - E. Dal Covolo - M. Maritano, Introduzione ai Padri della Chiesa. Secoli II e III, Torino 1998 ${ }^{3}, 80-176$ (bibliografia: 174-176); W. Turek, La speranza in Tertulliano, Roma 1997 (bibliografia: 121-128); F. Chapot S. Deléani - F. Dolbeau - J.C. Fredouille - P. Petitmengin (curantibus), Chronica Tertullianea et Cyprianea 2001, REAug 48 (2002) 331-371. Podstawowe kierunki współczesnych badań nad Tertulianem prezentuje R. Braun, Approches de Tertullien. Vingt-six études sur l'auteur et sur l'oeuvre de Tertullien (1955-1990), Paris 1992; R. Uglione, Tertulliano. Teologo e scrittore, Brescia 2002; Cz. Mazur, Tertulian w Polsce. Bibliografia, PSP 29, Warszawa 1983, 5-29. 
1. „Wspaniała istota cielesna"3. W swoim najobszerniejszym dziele zatytułowanym Przeciw Marcjonowi Tertulian pisze:

\begin{abstract}
„Któż bardziej godny zamieszkania wśród dzieł Bożych, jak nie jego obraz i podobieństwo? I to zdziałała dobroć najpracowitsza. Nie słowem rozkazującym, ale ręką przyjazną, po uprzednim przymilnym słowie: «Uczyńmy człowieka na Nasz obraz i podobieństwo Nasze». Dobroć powiedziała, dobroć ulepiła z mułu tak wspaniałą istotę cielesną, $\mathrm{z}$ jednej materii obdarzoną tyloma zdolnościami; dobroć tchnęła i powstała dusza, nie martwa, ale żywa; i dobroć ją postawila nad wszystkimi stworzeniami, którymi miała się żywić, nad którymi królować, nawet je nazywać”“
\end{abstract}

Nietrudno dostrzec w przytoczonym fragmencie niektóre teoretyczne zamierzenia Tertuliana. Kilkakrotne powtórzenie rzeczownika „dobroć” (bonitas) w odniesieniu do Boga Stworzyciela ma na celu odrzucenie teorii Marcjona, wedle której istnieje „fałszywy” Bóg Starego Testamentu i „prawdziwy” opisany w Nowym Testamencie. Tertulian opowiada się jasno w całym swoim dziele za istnieniem jednego Boga, odznaczającego się dobrocią w odniesieniu do wszelkiego swojego stworzenia, a zwlaszcza do czlowieka.

Już w samym akcie stworzenia pisarz dostrzega pewną różnicę w zachowaniu się Boga: stwarza On człowieka nie rozkazem („Niech się stanie”), ale „ręką przyjazną, po uprzednim przymilnym słowie: «Uczyńmy człowieka na Nasz obraz i podobieństwo Nasze»”. Bóg stwarza w ten sposób „wspaniałą istotę cielesną" (tanta substantia carnis), która ma królować nad wszystkimi innymi stworzeniami, nimi się odżywiać, a nawet je nazywać. Owa dobroć stwarzającego Boga przejawia się również w tym, że człowiek może poznawać swojego Stwórcę:

„Pierwszą przecież dobrocią Stworzyciela (bonitas Creatoris), dzięki której Bóg nie chcial się ukrywać na wieki, było, aby nie był czymś, przez co Bóg byłby niepoznawalnym"s.

Wcześniej Tertulian uzasadnia, że Boga poznaje się z jego dzieł, które sam uczynił, łącznie z materią, którą stworzył i ukształtował. Człowiek, dzięki dobroci Stworzyciela, poznaje Boga i owoce Jego działania.

Przywileje, jakie człowiek otrzymuje od Stworzyciela, stanowią o jego wyjątkowej pozycji i stawiają go na szczycie w hierarchii stworzeń. Co więcej, autor przewiduje dla człowieka dwa mieszkania: pierwsze na ziemi, drugie w niebie. W przypadku czlowieka można zatem mówić o szczególnych jego początkach jak też wyjątkowej rzeczywistości zarezerwowanej dla niego na przyszłość:

${ }^{3}$ Tertullianus, Adversus Marcionem II 4, 4, CCL 1, 478: „tantam substantiam carnis”, thum. S. Ryznar, PSP 58, Warszawa 1994, 73.

${ }_{4}$ Tamże, II 4, 3-4, CCL 1, 478-479, PSP 58, 73.

5 Tamże II 3, 2, CCL 1, 477, PSP 58, 71. 
„Jeżeli więc dobroć samego Boga przyczynila się do poznania Boga przez człowieka, to również do tego swojego orędzia dodała i to, że pomyślała o pierwszym domostwie człowieka, a potem o ogromnym pałacu, wreszcie o największym, aby w wielkim jak i w mniejszym wypróbowal się i postąpil naprzód, i tak od dobra Bożego, to jest od wielkiego aż do najlepszego nawet mógl przechodzić, aż wreszcie do większego się dostal mieszkania"

Człowiek bowiem jest w rzeczywistości szczególnym dziełem stwarzającego Boga, który obdarza go tyloma zdolnościami, mając na uwadze przyszłe Wcielenie swojego Syna.

2. „Na obraz Boży go stworzyl, to znaczy na obraz Chrystusa"”. W dziele Przeciw Marcjonowi Tertulian, analizując tekst $\mathrm{Rdz}$ 1, 26, określa czlowieka jako obraz i podobieństwo Chrystusa. Tego typu interpretacja omawianego wyrażenia biblijnego była już w myśli chrześcijańskiej zaproponowana wcześniej, zwłaszcza w tzw. tradycji teologicznej azjatyckiej, której jednym z twórców i reprezentantów jest Ireneusz. Biskup Lyonu pytając się kim jest ten człowiek konkretny, stworzony na „obraz i podobieństwo” Boże, dopatruje się związku między stworzeniem i zbawieniem, między pierwszym człowiekiem i Słowem Bożym, mającym przyjąć ludzkie ciało. Ireneusz stwierdzał konsekwentnie, że prawdziwe znaczenie tekstu $\mathrm{Rdz}$ 1,26 zostało ukryte przed ludzkością aż do czasu Wcielenia Syna Bożego; dopiero od tego momentu stało się jasne, że podmiotem tego obrazu jest Chrystus i dostrzeżono szczególny związek między chrystologią (Chrystus obrazem Boga) i antropologią (człowiek obrazem Chrystusa) ${ }^{8}$. Tertulian podejmując i pogłębiając $w$ podobnym duchu niektóre idee szkoły azjatyckiej stwierdza:

„A nasz Chrystus powinien był to wypowiedzieć: «Uczyniony jestem przez Ojca niewiele mniejszym od aniołów», a jednak: «robakiem a nie człowiekiem, pośmiewiskiem ludzi i wzgardą pospólstwa», albowiem tak chcial, abyśmy zostali uzdrowieni przez jego sińce, aby nasze zbawienie wyrosło z jego pohańbienia. I słusznie położył się na krzyż za swojego człowieka, za swój obraz i za swoje podobieństwo, a nie czyjeś obce"

Stwierdzając że człowiek został stworzony na obraz Syna Bożego, Tertulian ma na uwadze Słowo Wcielone, a nie obraz niewidzialny. Nie bez powodu pisarz mówi w tekście przed chwilą przytoczonym o człowieku, obrazie i podobieństwie

${ }^{6}$ Tamie II 4, 1, CCL 1, 478, PSP 58, 72.

${ }^{7}$ Tertullianus, De resurrectione mortuorum 6, 4, CCL 2, 928: „Ad imaginem Dei fecit illum, scilicet Christi", thum. W. Turek, Tertulian, OŻ 15, Kraków 1999, 163.

${ }^{8}$ Por. V. Grossi, Lineamenti di antropologia patristica, Roma 1983, 43-44. Autor rozprawy dodaje, że idea wedle której biblijny tekst $\mathrm{Rdz} 1,26$ należy odnosić do przyszłego Słowa Wcielonego, była wskazana już przed Ireneuszem przez Justyna, Pseudo-Barnabę i Teofila (s. 45).

${ }^{9}$ Adversus Marcionem IV 21, 12, CCL 1, 600, PSP 58, 193-194. 
Chrystusa, w kontekście Jego męki. Co więcej, Tertulian uważa, że już w momencie, gdy Bóg stwarzal człowicka, miał na uwadzc przyszle Słowo Wcielone:

„Jakikolwiek bowiem byłby kształt, który Bóg nadawał wówczas prochowi ziemi, miał On na myśli Chrystusa, przyszłego czlowieka, to jest i proch ziemi, i Słowo Ciało, które wówczas było ziemią. Tak bowiem Ojciec powiedzial do Syna: «Uczyńmy czlowieka na Nasz obraz, podobnego nam. Stworzył więc Bóg czlowieka», to właśnie dzieło, które ukształtował, «na obraz Boży go stworzył», to znaczy na obraz Chrystusa"10.

Konsekwentnic stworzenie zostaje ujęte w tekście Tertuliana jako figura i antycypacja Wcielenia, które w takim razie nie jest uwarunkowane przez grzech, jak to uważał Orygenes. Autor dzieła $O$ zasadach nie mógl, pod wpływem idealizmu platońskiego, traktować przyjęcia ciała inaczej jako konsekwencję upadku i odwrócenia się od Boga. U Tertuliana relacja między stworzeniem człowieka i Wcieleniem Syna Bożego staje się zwrotna: pierwsza zapowiada drugą, druga nadaje głębszy sens pierwszej. Już w momencie stworzenia człowieka Bóg nadaje mu szczególną godność ukazaną przez swoisty kontrast istniejący między prochem, z którego Stworzyciel „modeluje” człowieka, i jego powołaniem do tego, by być obrazem Syna Bożego, który kicdyś stanie się człowiekiem. Stworzony w takim kontekście człowiek otrzymuje niektóre cechy, które odróżniają go od pozostałych stworzeń, a przede wszystkim wolność rozumianą przez Tertuliana jako dar i zadanie.

\section{3. „Bóg stworzył czlowieka wolnym” "11. Tekst $\mathrm{Rdz} 1,26$ jest interpretowany} przez Tertuliana również w kontekście wolności, jaką człowiek został obdarzony przez swojego Stworzyciela. Zdaniem pisarza:

„Wypadało przeto, by obraz i podobieństwo Boga było obdarzone wolną wolą i możnością swego wyboru, na której to wolności i możności sam przez się obraz i podobieństwo do Boga zasadza. A do tego sama istota czlowieka jest przystosowana, aby był takiego stanu, mianowicie wolny w wyborze i władzy nad sobą, dzięki tchnieniu Boga. Inaczej bowiem jakżeby to wyglądało, aby człowiek posiadający władzę nad całym światem nie miał najpierw władzy nad swoim rozumem i nie królował nad nim on jako pan nad innymi, sługa samego siebie?"12.

Marcjon, podobnie zresztą jak gnostycy, odrzucal w pewnej mierze wolność woli człowieka; Tertulian - przeciwnie - właśnie w wolnej woli dostrzegat najważniejsze podobieństwo człowieka do Boga. Polemizując z Marcjonem,

${ }^{10}$ De resurrectione mortuorum 6, 3-4, CCL 2, 928, OŻ 15, 163.

11 Adversus Marcionem II 5, 5, CCL 1, 480: „Liberum et sui arbitrii et suae potestatis invenio hominem a Deo institutum", PSP 58, 74.

${ }_{12}$ Tamże, II 6, 3, CCL 1, 481, PSP 58, 75. 
starał siç usprawiedliwić prawo dane przez Boga czlowiekowi, krytykowane przez Marcjona. Prawo, którego celem jest strzec człowieka, zakłada jego wolność i odróżnia go od zwierząt. Człowiek jako zwierzç rozumne (animal rationale), władające rozumem i wiedzą (intellectus et scientiae capax), ma poddać wolność rozumną (libertas rationalis) Bogu, który mu podporządkował wszystko ${ }^{13}$. Pisarz stara się przekonać Marcjona i swoich czytelników, żc prawo nie wyklucza wolności, ale ją wzmacnia. Chodzi w rzeczywistości o subtelne i fundamentalne rozróżnienie między wolą Bożą i wolą ludzką: zdarza się, już od czasów Adama, że człowiek może wybrać swoją wolę przeciw woli Boga, otrzymał bowiem od niego ów dar wyboru. Otrzymał też jednak dar rozumu, dzięki któremu poznaje Boga z jego dzieł i przekonuje się, że Bóg chce dla niego wyłącznie dobra; człowiek konsekwentnie pragnic dla swojego dobra poznawać wolę Bożą i świadomie ją wybiera.

Prawo dane przez Boga czlowiekowi jest przejawem jego szczególnej godności, podobnie jak wolność, którą Bóg wyróżnił człowieka. Pisarz szczególnie wyraźnie podkreśla związek wolnego wyboru z biblijnym określeniem człowieka jako obrazu Boga:

„Widzę, że Bóg stworzył czlowieka wolnym i w jego sądzie, i w woli, i w możności wyboru, a nie spostrzegam żadnego innego podobieństwa do Boga i Jego obrazu jak właśnie ten stan i tę formę"14.

Tertulian w zwięzły, charakterystyczny dla siebie sposób, tym zdaniem podsumowuje dotychczasowy wywód na temat człowieka, obrazu Bożego. Fakt, że człowiek otrzymał od Boga dar możliwości wyboru, w najdobitniejszy sposób (nullam magis) wyraża biblijną koncepcję stworzenia człowieka na obraz i podobieństwo Boże; bardziej zatem niż to, że człowick ma królować nad innymi stworzeniami, jak też fakt, że już w czasie stworzenia Bóg miał w swoim umyśle Słowo, które kiedyś stanie się ciałem. Wolność jest ważną cechą człowieka, wyrażoną w słowach „obraz” i ,podobieństwo" zamieszczonych w tekście Rdz 1, 26; nie wyczerpuje ona jednak całej treści tych dwóch wieloznacznych terminów. Zdaniem bowiem Tertuliana, szukając ich sensu, trzeba też wziąć pod uwagę obydwa komponenty człowieka, tzn. duszę i ciało.

4. „Dusza, którą naznaczony jest na kształt Boga”15. Pisarz upatruje w duszy ludzkicj fundament zapewniający człowiekowi wolność i możność wyboru:

„Przecież nie wyraża podobieństwa do Boga ani twarz, ani linie ciała - tak przeróżne u rodzaju ludzkiego, ale ta istota, którą otrzymal od samego Boga, to jest

\footnotetext{
${ }^{13}$ Por. tamie, II 4, 5, CCL 1, 479, PSP 58, 73.

14 Tamże, II 5, 5, CCL 1, 480, PSP 58, 74.

15 Tamże, II 5, 6, CCL 1, 480: „Anima, ad formam Dei [...] signatus est”, PSP 58, 74.
} 
dusza, którą naznaczony jest na kształt Boga, bo ona zapewnia mu wolność jego sądu i możność wyboru"16.

W człowieku, stworzonym na obraz i podobieństwo Boże, szczególne „miejsce” zajmuje i szczególną rolę odgrywa dusza, odznaczająca się wyjątkowym pochodzeniem; cały człowiek stworzony jest przez Boga, ale tylko o duszy Tertulian stwierdza, że człowiek otrzymał ją bezpośrednio od samego Boga (quam ab ipso Deo traxit).

Warto zwrócić uwagę na niektóre terminy użyte przez Tertuliana odznaczającego się, jak wiadomo, szczególnie bogatym słownictwem. Pisarz określa Boga przymiotnikiem uniformis; oznacza on dosłownie: jednolity, jednakowy, jednostronny, który odnosi się do konkretnego znaczenia terminu forma (ksztatt, postać, wygląd). W zdaniu Tertuliana chodzi zatem o jedność boską, która charakteryzuje się nieobecnością wielości form ${ }^{17}$. Warto dodać, że idea wedle której człowiek wyraża nie w swoim ciele, ale w duszy „obraz i podobieństwo" Boże, została przedstawiona już przez Filona Aleksandryjskiego, a następnie przyjęta i wzbogacona przez wielu przedstawicieli okresu patrystycznego ${ }^{18}$.

Komentując tekst Rdz 1, 26 i ukazując dobroć Boga, Tertulian polemizuje ze zwolennikami Marcjona i odrzuca ich teorię dotyczącą upadku czlowieka, pytając: „Jeżeli Bóg jest dobry i przewidujący przyszłe i możliwe do odwrócenia zło dzięki swojej potędze, to dlaczego dopuścil, aby człowiek i to obraz i podobieństwo Jego, co więcej, jego istota (substantia sua), mianowicie dzięki godności duszy, popadł w śmierć, oszukany przez diabła?"19.

Tertulian określając człowieka jako substantia sua, tzn. substancja boska, pragnie, jak wynika z kontekstu, uwydatnić przede wszystkim dwa elementy: pierwszy odnosi się do ciała człowieka, należącego do Stwórcy, drugi natomiast do duszy, której pochodzenia należy dopatrywać się w samym Bogu. Czytając dalszy ciąg tekstu, zauważa się, że pisarz podkreśla coraz mocniej znaczenie duszy, stworzonej w każdym pojedynczym przypadku bezpośrednio przez Boga. W niej właśnie, wziętej z Boga, teolog dostrzega „obraz i podobieństwo Boże". W substancji pochodzącej z Boga, tzn. w duszy, człowiek został obdarowany wolnością na obraz Boży.

Ten szczególny przymiot duszy ludzkiej zostaje ukazany przez Tertuliana również przez inny termin techniczny, mianowicie afflatus Dei. Zostaje on użyty w tekście, w którym pisarz mówi o szczególnym pragnieniu Boga, który

16 Tamze, PSP 58, 74-75.

17 Trzeba dodać, że ten sam pisarz objaśniając niektóre zagadnienia dotyczące Trójcy Świętej, używa słowa forma, by jej treść przeciwstawić terminowi substantia: zob. J . Moingt, Théologie trinitaire de Tertullien. Histoire, doctrine, méthodes, I, Paris 1966, 93-96.

18 Por. komentarz R. Braun, SCh 368 (Contre Marcion II 5, 6), s. 47, n. 2.

19 Adversus Marcionem II 5, 1, CCL 1, 479, PSP 58, 74. 
chce dać się poznać innym. W tym celu, dobrym i rozumnym, Bóg stworzył człowicka na swój obraz i podobieństwo i dał mu wszystko to, co jest potrzebne, aby poznać swojego Stworzyciela:

„A do tego sama istota człowieka jest przystosowana, aby był takiego stanu, mianowicie wolny w wyborze i władzy nad sobą, dzięki tchnieniu Boga (afflatus Dei) ${ }^{\prime 20}$.

Dusza, którą człowiek otrzymuje od Boga, stanowi Jego cenny dar, znak szczególnej boskiej dobroci; w duszy człowiek wyraża „obraz i podobieństwo" Boże. Pisarz jednak daleki jest od tego, by w skomplikowanym kontekście doktrynalnym przełomu II i III wieku nie docenić w egzegezic tekstu $\mathrm{Rdz}$ 1,26 również znaczenia drugiego komponentu ludzkiego tzn. ciała.

5. „Cialo jest podstawą zbawienia”"21. Cialo ludzkie cieszy się - wedhug Tertuliana - szczególną godnością ${ }^{22} \mathrm{i}$ również jemu zostaje przypisany atrybut obrazu Bożego. Tertulian, idąc znowu po śladach Ireneusza, wychwalał fizyczny komponent człowieka; było to szczególnie ważne w kontekście rozwijającej się ciągle doktryny platońsko-gnostyckiej, wedle której to co materialne nie jest zdolne do przyjęcia zbawienia. Niektóre stwierdzenia Tertuliana wydają się w tym kontekście szczególnie interesujące:

„Wystarczy fakt, że żadna dusza nie jest w stanie otrzymać zbawienia, jeśli nie uwierzy gdy jest $w$ ciele; tak więc ciało jest podstawą zbawienia. Kiedy dusza jest usprawiedliwiana przez Boga, właśnie ciało sprawia, że może ona być przez Niego wybrana"23.

Tertulian uwydatniał mocno w swoich dziełach dotyczących zagadnień antropologii jedność czlowieka i określał konsekwentnie pojęciem homo nie tylko duszę, ale również ciało: „Człowiek bowiem jest zarówno ciałem jak też duszą" 24 . Ciało jest tak mocno związane $z$ duszą, że tworzy z nią jedność, nawet

${ }^{20}$ Tamże, II 6, 3, CCL 1, 481: „In quam rem ea substantia homini accommodata est, quae huius status esset, afflatus Dei, utique liberi et suae potestatis", PSP 58, 75. Bóg stwarza duszę ludzką tchnieniem, jak to ukazuje tekst $\mathrm{Rdz} 2,7$ i komentuje Tertulian w rozdziale dziewiątym II księgi Przeciw Marcjonowi, omawiając pojęcia afflatus i spiritus. Dusza ludzka jest powolana do istnienia przez tchnienie Boże, a nie przez Jego Ducha; z tego powodu nie należy jej przypisywać w sposób konieczny tej samej natury Bożej. Fakt ten nie pomniejsza jednak wyjątkowego charakteru duszy ludzkiej i jej szczególnej roli w zamiarze boskim.

21 De resurrectione mortuorum 8, 2, CCL 2, 931: „Caro salutis est cardo”, OŻ 15, 165.

22 Por. S. Stręikowski, Godność ciata w polemice Tertuliana przeciwko pogladom filozofów greckich na podstawie „De resurrectione mortuorum”, VoxP 22 (2002) t. 42-43, 377-390. Autor konkluduje: „Zasadniczym elementem argumentacji jest fakt stworzenia czlowieka przez Boga na Jego obraz i podobieństwo. Ciało ludzkie jako cel posiada właśnie uczestnictwo w podobieństwie Boga" (tamże, s. 389).

${ }^{23}$ De resurrectione mortuorum 8, 2, CCL 2, 931, OŻ 15, 165.

24 Tamże, 32, 8, CCL 2, 962: „Tam enim corpus homo quam et anima”. 
jeśli obydwa elementy spełniają różne zadania. Dusza i ciało są zjednoczone w spełnianiu każdego aktu ludzkiego, zarówno dobrego jak i złego, począwszy od grzechu pierworodnego 25 .

Jest rzeczą interesującą, że Tertulian przypisuje ciału atrybut obrazu Słowa Bożego, właśnie gdy komentuje opis stworzenia człowicka ${ }^{26}$; nawet jeśli koncepcja człowicka stworzonego na obraz i podobieństwo $(\mathrm{Rdz} 1,26)$ byla odnoszona do Chrystusa przed Tertulianem (Justyn, Pseudo-Barnaba, Teofil), trzeba przypisać Ireneuszowi i wlaśnie Tertulianowi wprowadzenie do tej koncepcji obrazu komponentu cielesnego. Czlowick, stworzony na obraz Chrystusa wcielonego, właśnie dziçki dziełu Chrystusa może realizować imago i similitudo, o których pisze tekst Rdz 1,26 . Szczególny związek między antropologią i chrystologią w myśli Tertuliana stanowi ważny element wyjaśnianej przez niego teorii zbawienia. Człowiek popadający w grzech odczuwał potrzcbç kogoś niewinnego, żeby móc na nowo realizować powołanie otrzymane od Chrystusa. Chrystus, Słowo Wcielone, przyjąl cialo i duszę, aby obydwa komponenty ludzkie mogły być zbawione, i umarł za wszystkich, aby wszyscy zostali uwolnieni od śmierci. Człowiek uczestniczy w dziele zbawczym Chrystusa i zostaje przez Nicgo wyniesiony do godności nie przysługującej mu z natury i nie wynikającej z samego faktu narodzin ${ }^{27}$.

Godność ciala ludzkiego i calego człowicka, który jest powolany do tego, aby uczestniczyć w życiu Bożym, zostaje ukazana przez Tertuliana równicż przez przyjęcie koncepcji Pawlowej, która nazywa nasze ciało „świątynią Boga”: „Czyż nie wiecie, żeście świątynią Boga i żc Duch Boży mieszka w was? Jeżeli ktoś zniszczy świątynię Boga, tego zniszczy Bóg. Świątynia Boga jest święta, a wy nią jesteście” (1Kor 3,16$)$. Paweł określa Kościól jako „świątyniç Boga"28: sam Duch Święty mieszka w chrześcijanach od momentu ich uwie-

${ }^{25}$ Por. A. Choi Yeong-Cheul, La, ,resurrectio carnis" secondo Q.S.Fl. Tertulliano (= Pontificia Studiorum Universitas Urbaniana. Pars Dissertationis ad Doctoratum in Theologia Dogmatica consequendum), Roma 1983, 27: „Sebbene Tertulliano impieghi parecchie volte il termine caro in senso peggiore nell'ambito morale, egli lo usa maggiormente per denotare l'esistenza terrena dell'uomo tutto intero".

${ }^{26}$ Ukazując niek tóre charakterystyki antropologii Tertuliana, korzystam m. in. z opracowania P. Siniscalco, Ricerche sul „De resurrectione” di Tertulliano, Roma 1966, 112-126. Tertulian, wedlug autora książki, w swojej antropologii „desume non poche nozioni della cultura del tempo e, cosa non sufficientemente rilevata, attinge a piene mani dal patrimonio di pensiero elaborato fino a quel momento dai precedenti scrittori cristiani" (s. 126).

${ }^{27}$ Por. Grossi, Lineamenti di antropologia, s. 92-94. Wyrażając tego typu teorie, Tertulian staje się jednym z najbardziej znanych reprezentantów szkoły teologicznej azjatyckiej, która rozpoczyna wyklad od rzeczywistosci wcielenia Słowa Bożego i proponuje koncepcję szeroko rozumianej jedności czlowieka; podkreśla przy tym rolę komponentu cielesnego człowieka, krytykowanego przez gnostyków, i salus carnis.

${ }^{28}$ Cytując odpowiednie teksty Starego Testamentu, Pawel powraca do tej koncepcji w 2Kor 6 , 16: „, Bo my jesteśmy świątynią Boga żywego - według tego, co mówi Bóg: Zamieszkam z nimi i będę chodził wśród nich, i będę ich Bogiem, a oni będą moim ludem"; zob. Kpł 26, 11-12; Ez 37, 27. 
rzenia i chrztu. Wydaje się jednak rzeczą dosyć skomplikowaną powiedzieć, czy Paweł ma na uwadze „zamieszkiwanie” Ducha Świętego w poszczególnym chrześcijaninie, czy raczej we wspólnocie chrześcijan. Można założyć, że obydwa wymiary uzupełniają się wzajemnie; człowiek otrzymuje Ducha w momencie, w którym wchodzi do wspólnoty ${ }^{29}$. Tekst, w którym Tertulian odwołuje się do autorytetu Pawła, proponuje egzegezę dosyć łatwą do zrozumienia:

„Paweł jest obecny również w tych słowach, kiedy mówi, że nosi w swoim ciele stygmaty Chrystusa, kiedy zabrania zanieczyszczać nasze ciało, które jest świątynią Boga, kiedy czyni z naszego ciała członki Chrystusa, kiedy nas upomina, abyśmy nosili i chwalili Boga w naszym ciele" ${ }^{30}$.

Tertulian, który w wielu swoich pismach i - w sposób szczególny - w traktacie $O$ zmartwychwstaniu zmarłych broni godności ciała ludzkiego ${ }^{31}$, interpretuje tekst Pawłowy o ciele - świątyni Boga w wymiarze indywidualnym: ciało chrześcijanina jest świątynią Boga. Troska, jaką Bóg okazuje w stworzeniu czlowieka, gwarantuje jego wartość, tym bardziej że Bóg stwarzając człowieka, miał na uwadze kształt, jaki przyjmie kiedyś Jego Syn w momencie Wcielenia.

Zwróciwszy uwagę na niektóre sposoby rozumienia tekstu $\operatorname{Rdz} 1,26$, jakie proponuje w swojej egzegezie Tertulian, warto podjąć jeszcze jedną - w jakimś stopniu uzupełniająca - kwestię. Człowiek „wspaniała istota cielesna”, stworzony „na obraz i podobieństwo Boże”, zajmuje szczególne miejsce w hierarchii stworzeń. Istniała już u źródeł myśli chrześcijańskiej pewna tendencja, oparta zresztą na niektórych danych biblijnych, by ukazać nie tylko wyjątkową pozycję daną człowiekowi w akcie stworzenia, ale też zarysować jego szczególną przyszłość i mówić - przynajmniej w jakimś wymiarze - o jego przebóstwieniu. Myśl ta, oparta m. in. na tekście $R \mathrm{dz} 1,26$, rozwinięta została bardziej w literaturze patrystycznej greckiej, ale też nie była obca autorom języka lacińskiego. Czy i ewentualnie co na jej temat mówił Tertulian?

6. „Jesteście bogami” (Ps 82, 6). W Psalmie 82, 6 czytamy: „Ja rzekłem: Jesteście bogami i wszyscy - synami Najwyższego". Zdanie to było wykorzystane przez niektórych pisarzy okresu patrystycznego jako fundament ich teorii przebóstwienia czlowieka. Spotykamy je również u Tertuliana, który w polemice przeciw Marcjonowi proponuje zupełnie oryginalną jego interpretację:

„Będziesz usiłował to oslabić rozważaniem o imieniu Boga, jako że za powszechnym zezwoleniem przenosi się je i na innych, ponieważ napisano: «Bóg powstaje

${ }^{29}$ Por. R. Penna, Prima Lettera ai Corinzi, w: AA. VV., Le Lettere di Paolo, Genova $1996^{2}, 62$.

${ }^{30}$ De resurrectione mortuorum $10,4, \mathrm{CCL} 2,933$, tlum. whasne ( W. Turek).

31 Por. na temat różnych definicji terminu caro u Tertuliana i godności ciała ludzkiego, studium J. Leal, La antropología de Tertuliano. Estudio de los tratados polémicos de los años 207-212 d.C., Roma 2001, 48-71. 
w zgromadzeniu bogów, pośrodku bogów sąd odbywa» oraz: «Ja rzekłem: jesteście bogami». Nic dlatcgo przysługuje im posiadanie najwyższej wielkości, ponieważ zostali nazwani bogami" ${ }^{32}$.

Tertulian odrzuca w dziele Przeciw Marcjonowi dualizm teologiczny Marcjona, analizując samo pojęcie Boga, który będąc summum magnum ${ }^{33}$, musi być koniecznie jedyny. Nic mamy pewności, ale być może Marcjon posłużył się przytoczonymi zdaniami Psalmu 82, aby opatrzyć również argumentem biblijnym swoją teorię dotyczącą istnienia dwóch bogów. Słowa Psalmu nie pozwalają, rzecz jasna, na interpretację, którą Tertulian przypisuje (nie wiemy na ile w sposób umotywowany) Marcjonowi. Zresztą już niektórzy myśliciele żyjący przed Tertulianem, komentując interesujące nas zdania Psalmu 82, wyjaśniali pojęcie „bogowie" w sensie odpowiedzialnych za administrację publiczną i wymiar sprawiedliwości ${ }^{34}$. Sam Tertulian jest dosyć daleki od interpretacji tekstu Ps $82 \mathrm{w}$ sensie idei przebóstwienia człowieka. W rzeczywistości, by uniknąć jakiejkolwiek wątpliwości, Tertulian podkreśla, że nikt nie może być równy Bogu:

„Najwyższa wielkość musi być jedyna, nie pozwala mieć sobie równej, ponieważ nie byłaby najwyższą wielkością. Nie istnieje zatem inaczej, jak przez to, przez co ma istnienie, to znaczy, że może być wyłącznie jedyna" ${ }^{35}$.

Tertulian zatem pokazuje - $\mathrm{z}$ jednej strony - szczególny rodzaj powołania i zadania, jakie człowick otrzymuje od Boga w hierarchii wszystkich stworzeń, lecz - z drugiej strony - wyraźnie wskazuje, również przez pojęcie summum magnum, transcendencję jedyną Boga chrześcijan:

„Mówimy o Bogu, którego to jest istotną właściwością, że nie dopuszcza porównania z żadną rzeczywistością [...]. Być może do rzeczy boskich można przyrównać rzeczy ludzkie, a do Boga natomiast nie można. Czymś innym bowiem jest Bóg, czym innym są rzeczy boskie" ${ }^{\prime 36}$.

Bóg i człowiek są różni w sposób istotny, nawet jeśli rzeczywistości boskie i te ludzkie mogą mieć jakieś podobieństwo.

${ }^{32}$ Adversus Marcionem I 7, 1, CCL 1, 447, PSP 58, 40.

33 Wyrażenie summum magnum, które streszcza refleksje Tertuliana o naturze boskiej, jest używane przez niego dosyć często; prawdopodbnie zostało też przez tego samego pisarza utworzone, por. R. Braun, ,Deus Christianorum”. Recherches sur le vocabulaire doctrinal de Terfullien, Paris $1977^{2}, 43-44$.

${ }^{34}$ Por. komentarz Bibbia di Gerusalemme, Bologna $1993^{12}$, 1213: „I principi e i giudici sono messi sullo stesso piano dei "figli dell'Altissimo", membri della corte divina. Il Cristo applica questo passo, in un contesto diverso, ai giudici istruiti nella parola di Dio".

35 Adversus Marcionem I 3, 5, CCL 1, 444, PSP 58, 36.

${ }^{36}$ Tamże I 4, 2, CCL 1, 445, PSP 58, 37. 
Jest rzeczą zadziwiająca, że Tertulian, który tymi zdaniami wyklucza owo admirabile commercium między Bogiem a człowiekicm, zaproponuje go w innym micjscu jako syntezę swojej myśli o szczególnym miejscu człowieka w hierarchii stworzeń, ukazanym już przez tekst Rdz 1,26.

\section{7. „Aby człowiek mógł dzialać na równi z Bogiem”37. Kontynuując swoją} myśl Tertulian dodaje:

„Obcował Bóg po ludzku, aby czlowiek nauczył się obcować po Bożemu. Wspóldziałał Bóg z czlowiekiem jakby równy jemu, aby człowiek mógl działać na równi z Bogiem. Bóg okazał się maluczkim, aby czlowiek stał się wielkim"38.

Przytoczony tekst stanowi pewien rodzaj podsumowania drugiego rozdziału dzieła Przeciw Marcjonowi, którego celem jest obrona Boga wyznawanego przez chrześcijan przeciw koncepcjom proponowanym przez Marcjona i jego zwolenników. Niektóre pojęcia dostrzeżone w przytoczonym fragmencie ukazują szczególną wymianę między Bogiem i człowiekiem, która realizuje się w sposób szczególny w misji i osobie Jezusa Chrystusa. Już pierwsza część tekstu: „conversabatur Deus humane”, przyciąga naszą uwagę z racji na czasownik conversari, który w dziełach Tertuliana wyraża, wraz z rzeczownikiem conversatio, przede wszystkim pewien sposób życia i pewną postawę. W rzeczywistości dwa pojęcia: praedicatio i conversatio ukazują w myśli Tertuliana dwa fundamentalne aspekty życia chrześcijan: pierwszy obejmuje treść doktrynalną religii chrześcijańskiej, drugi natomiast odnosi się do przestrzegania określonych norm w życiu codziennym, jak też do sprawowania praktyk i rytów ${ }^{39}$.

W tekście Przeciw Marcjonowi II 27, 7 czasownik conversari opisuje pewną postawę Boga, który „obcował po ludzku, aby czlowiek nauczył się obcować po Bożemu". Zdanie poza tym, że podkreśla inicjatywę Boga w odniesieniu do człowieka, ukazuje również jej cel: człowiek powinien nauczyć się żyć jak Bóg. Być może, spotykamy tutaj po raz pierwszy w literaturze chrześcijańskiej łacińskiej tego typu myśl, dotyczącą powołania ofiarowanego przez Boga człowiekowi i opisaną w typowy dla Tertuliana precyzyjny i zwięzły sposób słowami: Conversabatur Deus humane ut homo divine agere doceretur ${ }^{40}$; to stwierdzenie

${ }^{37}$ Tamże II 27, 7, CCL 1, 507: „Ut homo ex aequo agere cum Deo posset”, PSP 58, 100.

38 Tamże; w tych zdaniach można dostrzec obecność myśli Ireneusza o przebóstwieniu człowieka wyrażonej w Adversus haereses III 10, 2, SCh 211, 116-118: „Filius Dei Altissimi qui per legem et prophetas promisit Salutarem suum facturum se omni carni visibilem, ut fieret Filius hominis ad hoc ut et homo fieret filius Dei”; tamże III 19, 1, SCh 211, 374: „Propter hoc enim Verbum Dei homo, et qui Filius Dei est Filius hominis factus est, ut homo, commixtus Verbo Dei et adoptionem percipiens, fiat filius Dei".

39 Por. Adversus Marcionem IV 3, 4, CCL 1, 549, PSP 58, 145.

${ }^{40}$ Zaskakuje fakt, że R. Braun (zob. SCh 368,164 ) opuszcza w wydaniu krytycznym dzieła Tertuliana slowo humane, które odnajdujemy w edycji A. Kroymann (zob. CCL 1, 507). Być może, historia manuskryptów traktatu Tertuliana Przeciw Marcjonowi ukazuje potrzebę tego typu opusz- 
Tertuliana można traktować - w jakiejś mierze - jako konsekwencję jego egzegezy tekstu $\mathrm{Rdz} 1,26$. Słowo agere zastosowane przez Tertuliana może wyrażać różne znaczenia w łacinie klasycznej; zachowywać się w taki czy inny sposób, przebywać, żyć, istnieć, dzialać; wydaje się rzeczą dosyć trudną wskazać główny sens, jaki miał na uwadze pisarz używając tego terminu. Bez wątpienia jednak Tertulian pragnie podkreślić całe bogactwo relacji między Bogiem i człowiekiem. Przysłówek divine, który poprzedza kluczowe słowo tego zdania, uwidacznia sposób typowy dla zachowania się Boga i, jednocześnie, cel, do którego jest powołany człowick.

Po pierwszym opisie tego szczególnego powołania, jakie człowick otrzymuje od Boga i które w sposób szczególny będzie realizowane w przyszłości, Tertulian ukazuje je jeszcze $w$ inny sposób podkreślając aspekt przeszłości: „Współdziałal Bóg z człowiekiem jakby równy jemu, aby człowiek mógł działać na równi z Bogiem". Zdanie streszcza całą Bożą działalność dla dobra człowieka $\mathrm{i}$ - w sposób szczególny - dzieło dokonane przez Jezusa Chrystusa. Bóg nie mógłby współdziałać na równi z człowiekiem, jeśli nie przyjąłby ludzkich zmysłów i uczuć, poprzez które „zmniejsza” swoją wielkość. W rzeczywistości bowiem chodzi o ,upokorzenie się, jego wprawdzie niegodne, ale dla człowieka konieczne, a stąd też godne Boga, bo nic tak nie jest Boga godne jak zbawienie człowicka"41.

Wielki Bóg staje się mały, by zmienić położenie człowieka; oto zatem trzecia część przytoczonego wyżej i analizowanego tekstu: „Bóg okazał się maluczkim, aby czlowiek stał się wielkim" (Deus pusillus inventus est, ut homo maximus fieret). Zwolennicy Marcjona krytykowali niektóre czyny Jezusa (ich zdaniem niegodne), które $\mathrm{z}$ kolei Tertulian interpretował pozytywnie, ukazując w nich przejaw dowartościowania człowieka ze strony Boga; Syn Boży jednoczy w sobie w sposób pełny to co boskie i ludzkie ${ }^{42}$.

Afrykańczyk ukazując admirabile commercium między Bogiem i człowiekiem, które realizuje się w sposób szczególny w osobie Jezusa Chrystusa, określa Syna jako Tego, który „złączył w sobie i człowieka i Boga, to znaczy w mocy i w cnotach - Boga, w małostkowościach zaś - człowieka, aby tyle uźyczyć człowiekowi, ile ujmuje Bogu,43.

czenia? Jednak z punktu widzenia retoryki użycie wspomnianego słowa wydaje się usprawiedliwione przez paralelizm: humane - divine.

${ }^{41}$ Adversus Marcionem II 27, 1, CCL 1, 505, PSP 58, 99

42 Temat jednoczesnej obecności czlowieka i Boga w Chrystusie zostal przedstawiony przez Tertuliana już w traktacie Apologeticum 21,14, CCL 1, 125, gdzie Tertulian używa charakterystycznego dla siebie zwrotu w odniesieniu do Chrystusa: „homo Deo mixtus” (człowiek złączony z Bogiem), tlum. J. Sajdak, POK 20, Poznań 1947, 95.

${ }^{43}$ Adversus Marcionem II 27, 6, CCL 1, 506-507: „Miscente in semetipso hominem et Deum, in virtutibus Deum, in pusillitatibus hominem, ut tantum homini conferat quantum Deo detrahit", PSP 58, 100. 
Tertulian jako pierwszy spośród lacinników podjąl, w skomplikowanym kontekście doktrynalnym (gnostycyzm, marcjonizm), próbę opracowania teologii „obrazu i podobieństwa”, wyjaśniając w wielu miejscach swoich dziel, jak należy rozumieć tekst $\mathrm{Rdz} 1,26$. Rozpoczynając od dosłownej interpretacji biblijnego tekstu, która jasno ukazuje szczególne miejsce czlowieka w hierarchii stworzeń, pisarz dochodzi następnie do śmiałych wniosków natury doktrynalnej. Określa przede wszystkim czlowieka jako „obraz i podobieństwo Chrystusa”, dokonując w ten sposób połączenia, równicż na płaszczyźnie tekstu $\mathrm{Rdz} 1$, 26, refleksji antropologicznej i chrystologicznej. Ukazuje następnie wolność człowieka jako element esencjalny „obrazu”, której nic jest on pozbawiony nawet przez grzech pierworodny, i wypływającą z niej odpowiedzialność za czyny. Umieszcza następnie „obraz i podobieństwo" Boże w obydwóch komponentach czlowieka, tzn. w duszy i w ciele, ponieważ żaden $z$ nich sam nie może ich wyrażać. Podkreślając wyraźnie jedność człowieka i zarysowując myśl o jego przebóstwieniu, Tertulian ukazuje, że „obraz i podobieństwo" są nie tylko czymś danym, ale też zadanym człowiekowi, który jest powołany do tego, aby poprzez wlasne zaangażowanie działać w sposób coraz pełniejszy prawie „na równi z Bogiem”.

\section{„FACCIAMO L'UOMO A NOSTRA IMMAGINE, A NOSTRA SOMIGLIANZA" GEN 1, 26 NELL'INTERPRETAZIONE DI TERTULLIANO}

\section{(Riassunto)}

Tertulliano per primo tra gli autori latini, in un contesto dottrinale assai complesso (lo gnosticismo, il marcionismo), propone una teologia dell' ,immagine e della somiglianza", interpretando in molti dei suoi scritti il testo biblico di Gen 1, 26. Partendo dall'esegesi, che dimostra chiaramente un posto privilegiato dell'uomo tra le altre creature, lo scrittore sviluppa talune idee di carattere dottrinale. Definisce soprattutto l'uomo come ,immagine e somiglianza" di Cristo, aggiungendo, anche in base del Gen 1, 26, la riflessione antropologica e cristologica. Presenta poi la libertà dell'uomo come elemento essenziale dell'immagine e della responsabilità che ne consegue. Colloca infine "l'immagine e la somiglianza" in tutte e due le componenti dell'uomo, cioè nell'anima e nella carne, anche perché nessuna di esse può definirle da sola. Sottolineando fortementc l'unità dell'uomo e proponendo, almeno in maniera introduttiva, l'idea della divinizzazione dell'uomo, Tertulliano dimostra che „l'immagine e la somiglianza” sono non solo un dono, ma richiedono altresì un impegno da parte dell'uomo, il quale è destinato in maniera scmpre più profonda a trattare quasi ,alla pari con Dio". 